Non-Member registration fee and the two all-access Saturday and Sunday registrations. On-site fees will apply on or after March 28, 2014.

\section{Allied Health Discount Package-SAVE 45\% (Savings of \$225)}

Allied Health who pre-register for the Annual Meeting (Monday, April 28 to Wednesday, April 30), all access for Saturday and all access for Sunday will only be charged \$275. On or after March 28, 2014, the rate will be \$375.

\section{International Attendees}

Please be sure to check with your local embassy or consulate regarding the required travel documents for visiting Canada.

For more information, please visit: www.cbsa.gc.ca and www.cic.gc.ca.

If you require a letter of invitation from the AATS, please visit www.aats.org.

For more information, please visit www.aats.org/annual meeting.

\section{The American Association for Thoracic Surgery Journals}

\section{Seminars in Thoracic and Cardiovascular Surgery}

The Editors of Seminars in Thoracic and Cardiovascular Surgery want to call your attention to a couple of pieces in the Fall 2013 issue. The first is the expert roundtable on "Discussions in Cardiothoracic Treatment and Care: Management of the Apical Tumor." This hot topic features a spirited conversation between noted experts Drs Manjit Bains, Stephen Swisher, and Eric Vallières, moderated by Dr Jessica Donington. During this nearly two-hour-long discussion, views on topics such as timing, institutional protocols, palliation of pain, and outcomes are compared between authorities in the field. For an excerpt and more highlights from this discussion, please go here: http:// www.semthorcardiovascsurg.com.

\section{New in 2014-Save the Date}

AATS Cardiovascular Valve Symposium

September 4-6, 2014

Hilton Istanbul, Istanbul, Turkey

\section{Program Directors}

David H. Adams

Mount Sinai School of Medicine

New York, New York, USA

\section{Sertac Cicek}

Anadolu Medical Center

Istanbul, Turkey

Joseph S. Coselli

Baylor College of Medicine

Houston, Texas, USA

Pedro J. del Nido

Children's Hospital

Boston, Massachusetts, USA

For more information, visit www.aats.org/valveistanbul

The Editors would also like to make mention of the article, "Current Status of TAVR" by Drs Robert Bonow, Lars Svensson, and Eric Roselli. The article discusses patient selection in the PARTNER trial and important indications for and improvements expected following TAVR. The "Current Status of TAVR" is in the News and Views section of the Fall 2013 issue.

\title{
Operative Techniques in Thoracic and Cardiovascular Surgery
}

The Editor of Operative Techniques in Thoracic and Cardiovascular Surgery would like to draw your attention to the Fall 2013 issue. The techniques described in this issue include the double switch procedure for ccTGA, Belsey-Mark IV repair, robotic repair of giant paraesophageal hernia, and mechanical circulatory support for the failing left ventricle. Each topic is described by expert surgeons in great technical detail, complete with outcomes of their technique and illustrations that outline each step of the procedure.

\section{The Western Thoracic Surgical Association}

The St. Regis Monarch Beach

Dana Point, California

\section{WTSA 40th Annual Meeting}

Save the Date!

June 25-28, 2014

\section{Applications for Membership}

The WTSA is now accepting Applications for Membership online for Active as well as Candidate membership status. Visit the WTSA Web site at www.westernthoracic.org to 